\title{
Pengaruh Pelatihan Stimulasi Keluarga oleh Ibu dalam Bentuk Tulisan dengan Gambar terhadap Perkembangan Anak Usia Kurang dari 3 Tahun
}

\author{
Innike, Asri Purwanti \\ Departemen Pediatri Fakultas Kedokteran Universitas Diponegoro/ RSUP Dr. Kariadi, Semarang
}

\begin{abstract}
Latar belakang. Tumbuh kembang anak dipengaruhi oleh faktor genetik dan lingkungan. The Golden Age merupakan kurun usia terpenting dalam kehidupan manusia. Kementerian Kesehatan dan Ikatan Dokter Anak Indonesia telah menyusun buku pedoman pelaksanaan stimulasi, deteksi, dan intervensi dini tumbuh kembang anak di tingkat pelayanan kesehatan dasar (KPSP). Buku ini dapat digunakan oleh tenaga medis dan paramedis.

Tujuan. Membuktikan perbedaan pengaruh stimulasi keluarga oleh ibu dengan menggunakan buku KPSP jika diterapkan dalam bentuk tulisan dengan gambar terhadap perkembangan anak.

Metode. Quasi eksperimental dengan subjek anak usia kurang dari 3 tahun yang memenuhi kriteria inklusi. Pengambilan subjek secara simpel random sampling. Subjek dibagi menjadi dua kelompok. Kelompok satu, anak yang ibunya mendapat pelatihan dengan buku KPSP bentuk gambar. Kelompok dua, anak yang ibunya mendapat pelatihan stimulasi dengan buku KPSP bentuk tulisan. Perkembangan anak dinilai dengan Denver-2, yaitu sebelum ibu mendapat pelatihan dan sesudah mendapat pelatihan pada akhir bulan ke-1, ke-3, dan ke-6. Analisis data dengan chi-square test, Hasil signifikan bila p<0,05 (95\% CI tidak melewati angka 1).

Hasil. Subjek 130 anak dengan rerata usia $(18,18 \pm 7,0)$ bulan. Pada kelompok satu, hubungan stimulasi keluarga oleh ibu terhadap perkembangan motor kasar dan motor halus $(\mathrm{p} \leq \mathbf{0 , 0 5} ; \mathrm{p} \leq \mathbf{0 , 0 5})$, personal sosial dan bahasa ( $\mathrm{p}=0,325 ; \mathrm{p}=0,089)$. Pada kelompok dua, hubungan stimulasi keluarga terhadap perkembangan motor kasar dan motor halus ( $\mathrm{p} \leq 0,05 ; \mathrm{p} \leq 0,05)$, personal sosial dan bahasa $(\mathrm{p}=0,75 ; \mathrm{p}=0,40)$.

Kesimpulan. Cara stimulasi oleh ibu dengan metode gambar lebih baik pengaruhnya terhadap perkembangan anak usia kurang dari tiga tahun dibandingkan dengan metode tulisan. Sari Pediatri 2014;16(4):284-91.
\end{abstract}

Kata kunci: stimulasi, tulisan, gambar, perkembangan

\footnotetext{
Alamat korespondensi:

Dr. Innike Kusumawaty. Departemen Pediatri Fakultas Kedokteran Universitas Diponegoro/ RSUP Dr. Kariadi Semarang J1. Dr. Sutomo 16 Semarang 50231. E-mail : ahmad_1_161@yahoo.com
}

$\longrightarrow$ umbuh kembang seorang anak dipengaruhi oleh faktor genetik dan faktor lingkungan. The Golden Age merupakan kurun usia terpenting dalam kehidupan manusia. 
Pada usia kurang dari 3 tahun, tumbuh kembang berjalan sangat cepat, khususnya jaringan otak dan syaraf. ${ }^{1}$ Perkembangan otak sangat kompleks, meliputi penambahan (proliferasi) sel, perpindahan (migrasi sel), perubahan (diferensiasi) sel, pembentukan jalinan saraf satu dengan yang lainnya (sinaps), dan pembentukan selubung saraf (mielinasi). ${ }^{2}$ Proses perkembangan otak itu terdiri dari berbagai tahapan, meliputi induksi neuroektoderm hingga pembentukan tabung saraf, lipatan cephalic, proliferasi neuron, migrasi, sinaptogenesis, dan pertumbuhan sel penyangga otak. ${ }^{3}$

Kementerian Kesehatan bekerjasama dengan Ikatan Dokter Anak Indonesia (IDAI) telah menyusun berbagai instrumen stimulasi, deteksi, dan intervensi dini tumbuh kembang untuk anak umur 0 sampai dengan 6 tahun. Instrumen tersebut diuraikan dalam buku "pedoman pelaksanaan stimulasi, deteksi, dan intervensi dini tumbuh kembang anak di tingkat pelayanan kesehatan dasar". ${ }^{4}$ Namun, selama ini, belum pernah ada penelitian mengenai perbedaan pengertian dan pemahaman ibu dalam menerapkan isi buku tersebut, bentuk tulisan dibandingkan dengan bentuk gambar terhadap perkembangan anak.

\section{Metode}

Penelitian quasi eksperimental, pre and post test design, lokasi penelitian di daerah Jatingaleh dan Srondol, Semarang pada bulan Mei 2012 sampai dengan Oktober 2012. Subjek penelitian dipilih secara simple random sampling. Subjek adalah semua anak usia kurang dari 3 tahun yang memenuhi kriteria inklusi, yaitu status gizi baik berdasarkan kurva $Z$-score. Subjek yang telah mendapat ijin tertulis dari orang tua diikutsertakan dalam penelitian .

Penekanan penelitian ini adalah memberi pengetahuan pada ibu tentang tahap perkembangan anak dan cara menstimulasi anak sesuai dengan usia perkembangan anak tersebut. Selanjutnya, ibu dapat menerapkan pengetahuan tersebut di rumah, berinteraksi, dan berkomunikasi dengan anak. Untuk mempermudah penyampaian, peneliti dibantu dengan alat permainan untuk stimulasi. Dalam memberikan stimulasi anak di rumah, setiap orang tua subjek akan diberi buku panduan serta buku cerita bergambar dan alat permainan edukatif sesuai kelompok usia. Perbedaannya, pada kelompok 1, adalah kelompok anak yang ibunya diberi pelatihan berdasar buku panduan KPSP gambar, sedangkan pada kelompok 2, adalah kelompok anak yang ibunya diberi pelatihan berdasar buku KPSP tulisan.

Semua subjek akan dilakukan pemeriksaan OAE, kemudian dicatat data ibu/pengasuh, data klinis, HOME, dan Denver-2. Kunjungan rumah sebulan sekali, selama kunjungan petugas akan mengevaluasi langsung ibu/pengasuh saat bermain dan berinteraksi dengan anaknya serta lingkungan sekitar anak. Waktu kunjungan rata-rata 30 menit tiap kunjungan. Stimulasi ibu dinilai dengan HOME. Pengukuran perkembangan anak dinilai dengan Denver-2 sebelum dan sesudah ibu mendapat pelatihan pada akhir bulan pertama, tiga bulan berikutnya, dan akhir bulan ke enam. Pada saat pengukuran ulang, orang tua subjek dikumpulkan kembali untuk diberi pelatihan ulang cara menstimulasi anak. Evaluasi akan dilakukan untuk mencari kendala/hambatan yang dialami orang tua dalam menstimulasi anak serta pemecahannya. Pada akhir bulan keenam, hasil pengukuran akan dianalisis.

Uji hipotesis dengan menggunakan uji $\chi^{2}$, uji ini dipilih oleh karena variabel terikat dan variabel bebas berskala nominal. Batas kemaknaan adalah apabila $\mathrm{p} \leq 0,05$ dengan interval kepercayaan 95\%. Analisis data dilakukan dengan program komputer. Persetujuan keluarga diminta dalam bentuk informed consent tertulis. Identitas pasien dirahasiakan.

\section{Hasil}

Subjek 130 anak usia 0-30 bulan, 65 anak kelompok satu (stimulasi bentuk gambar) dan 65 kelompok dua (stimulasi bentuk tulisan). Tidak terdapat perbedaan antar kelompok tentang karakteristik subjek penelitian $(\mathrm{p}>0,05)$ (Tabel 1). Tidak terdapat perbedaan bermakna karakteristik pengasuh (Tabel 2).

\section{Pengaruh intervensi stimulasi keluarga terhadap perkembangan anak}

Instrumen pengukuran lingkungan perkembangan anak dinilai dengan HOME (home observation for measurement of the environment) yang menilai enam aspek, yaitu tanggap rasa dan kata, penerimaan terhadap perilaku anak, pengorganisasian lingkungan anak, penyediaan mainan, keterlibatan ibu, serta 
Tabel 1. Karakteristik anak

\begin{tabular}{|c|c|c|}
\hline Variabel & Kelompok satu $(n=65)$ & Kelompok dua $(\mathrm{n}=65)$ \\
\hline Usia (bulan) & $18,18 \pm 7,0$ & $17,12 \pm 7,0$ \\
\hline \multicolumn{3}{|l|}{ Jenis kelamin, $\mathrm{n}(\%)$} \\
\hline Laki-laki & $43(66,2)$ & $35(53,8)$ \\
\hline Perempuan & $22(33,8)$ & $30(46,2)$ \\
\hline \multicolumn{3}{|l|}{ Jumlah saudara (\%) } \\
\hline$\leq 2$ & $11(17)$ & $4(6,2)$ \\
\hline$>2$ & $54(83)$ & $61(93,8)$ \\
\hline \multicolumn{3}{|l|}{ Masa gestasi $(\%)$} \\
\hline Cukup bulan (aterm) & $61(93,8)$ & $62(95,3)$ \\
\hline Prematur & $2(3,1)$ & $2(3,1)$ \\
\hline Lewat bulan & $2(3,1)$ & $1(1,6)$ \\
\hline \multicolumn{3}{|l|}{ Riwayat persalinan (\%) } \\
\hline Normal & $57(87,6)$ & $56(86,1)$ \\
\hline Partus dengan tindakan & $8(12,4)$ & $9(13,9)$ \\
\hline \multicolumn{3}{|l|}{ Panjang badan lahir $(\%, \mathrm{~cm})$} \\
\hline$<48$ & $15(23,0)$ & $12(18,5)$ \\
\hline$\geq 48$ & $50(77,0)$ & $53(81,5)$ \\
\hline \multicolumn{3}{|l|}{ Berat badan lahir (\%, gram) } \\
\hline$<2500$ & $2(3,1)$ & $3(4,6)$ \\
\hline-4000 & $62(95,3)$ & $61(93,8)$ \\
\hline$>4000$ & $1(1,6)$ & $1(1,6)$ \\
\hline \multicolumn{3}{|l|}{ Riwayat Imunisasi (\%) } \\
\hline Lengkap & $65(100)$ & $65(100)$ \\
\hline Tidak lengkap & 0 & 0 \\
\hline \multicolumn{3}{|c|}{ Tinggi badan berdasar umur (\%) } \\
\hline Normal & $62(95,4)$ & $61(93,8)$ \\
\hline Pendek & $3(4,6)$ & $4(6,2)$ \\
\hline
\end{tabular}

Tabel 2. Karakteristik pengasuh

\begin{tabular}{lcc}
\hline Variabel & Kelompok satu $(\mathrm{n}=65)$ & Kelompok dua $(\mathrm{n}=65)$ \\
\hline Pengasuh (\%) & & \\
$\quad$ Ibu kandung & $61(93,8)$ & $62(95,4)$ \\
$\quad$ Selain ibu kandung & $4(6,2)$ & $3(4,6)$ \\
Pendidikan ibu (\%) & $51(78,5)$ & $47(72,4)$ \\
$\quad$ SMA & $10(15,4)$ & $11(16,9)$ \\
D3 & $3(4,6)$ & $4(6,1)$ \\
S1 & $1(1,5)$ & $3(4,6)$ \\
S2 & & \\
Pengetahuan ibu & $35(53,9)$ & $33(50,7)$ \\
tentang perkembangan anak (\%) & $30(46,1)$ & $32(49,3)$ \\
$\quad$ Cukup & & $6(9,2)$ \\
Kurang & $5(7,7)$ & $59(90,8)$ \\
Status Pekerjaan ibu (\%) & $60(92,3)$ & $65(100)$ \\
$\quad$ Bekerja & $65(100)$ & $5(7,7)$ \\
$\quad$ Tidak bekerja & & $3(4,6)$ \\
Sosial ekonomi ibu (\%) & 0 \\
$\quad$ Menengah & $1(3,0)$ & 0 \\
Riwayat Obstetri ibu (\%) & $1(1,5)$ & \\
$\quad$ Abortus & $1(1,5)$ & \\
$\quad$ Prematur & & \\
$\quad$ Lahir mati & &
\end{tabular}


kesempatan variasi asuhan anak.

Pada bulan pertama, anak yang mendapat stimulasi cukup, dikatakan cukup apabila total skor HOME $\geq 60$, baik pada kasus maupun kontrol hampir sama kisaran 63,48 dan 62,2. Hal ini berarti masih banyak anak yang kurang mendapat stimulasi (Gambar 1). Pada saat kunjungan rumah dilakukan evaluasi ulang. Ibu kembali dilatih cara stimulasi, kemudian dibimbing untuk mempraktekkan langsung ke anak. Bulan ketiga dan keenam terjadi peningkatan HOME. Ibu umumnya lebih mudah menangkap kata-kata petugas pada saat dilatih dengan menggunakan buku dalam bentuk gambar dari pada buku dalam bentuk tulisan.

Pada kelompok satu dan dua, bulan pertama penelitian, anak yang mendapat stimulasi cukup dan sesuai dengan usia perkembangannya hanya $35,4 \%$ dan mengalami peningkatan signifikan $80 \%$ dan $83,1 \%$ pada bulan ke-3 dan ke-6 pemantauan. Pada akhir bulan keenam pemantauan, Spearman's tes menunjukkan hubungan yang bermakna antara HOME dengan perkembangan anak baik pada kelompok satu maupun dua $(\mathrm{p}=0,000 ; \mathrm{p}=0,013)$.

Pada kelompok satu dan dua, bulan pertama penelitian, jumlah anak yang mendapat stimulasi cukup dan perkembangan motor kasarnya sesuai usia hanya $61,5 \%$ dan mengalami peningkatan $86,2 \%$ dan $92,3 \%$ pada akhir bulan ke-3 dan ke- 6 pemantauan. Spearman's tes menunjukkan hubungan yang bermakna antara stimulasi gambar dan tulisan terhadap perkembangan motor kasar anak $(\mathrm{p} \leq 0,05 ; \mathrm{p} \leq 0,05)$.

Pada kelompok satu, bulan pertama penelitian, jumlah anak yang mendapat stimulasi cukup dan perkembangan motor halus sesuai usia $52,3 \%$ dan mengalami peningkatan $84,6 \%$ dan $92,3 \%$ pada bulan ke-3 dan ke-6. Spearman's tes menunjukkan hubungan yang bermakna antara stimulasi gambar maupun tulisan dengan motor halus anak $(\mathrm{p}=0,002 ; \mathrm{p}=0,003)$.

Pada kelompok satu, bulan ke-3 dan ke-6, jumlah anak yang mendapat stimulasi cukup dan perkembangan personal sosial sesuai usia $92,3 \%$ dan $98,5 \%$. Spearman's tes menunjukkan hubungan yang bermakna antara pelatihan stimulasi bentuk gambar terhadap personal sosial anak pada bulan pertama dan bulan ke-3 ( $p=0,023 ; p=0,004)$, tetapi tidak ada hubungan pada bulan ke-6 $(\mathrm{p}=0,325)$. Pada kelompok dua, tidak didapatkan hubungan antara pelatihan stimulasi bentuk tulisan terhadap personal sosial anak $(\mathrm{p}=0,751)$.

Pada kelompok satu, bulan pertama penelitian, jumlah anak yang mendapat stimulasi cukup dan perkembangan bicara sesuai usia $80 \%$, lebih rendah dibandingkan kelompok dua (84,6\%). Namun, pada bulan ke-3 dan ke-6 pemantauan, kelompok satu justru meningkat melampaui anak dari kelompok dua, $89,2 \%$ dan $95,4 \%$. Spearman's tes menunjukkan hubungan yang bermakna antara pelatihan stimulasi bentuk gambar dengan kemampuan bicara/bahasa anak pada bulan pertama dan ke-3 pemantauan $(\mathrm{p}=0,000 ; \mathrm{p}=0,001)$, tetapi tidak pada bulan ke-6 pemantauan $(\mathrm{p}=0,089)$. Pada kelompok dua, tidak didapatkan hubungan antara pelatihan stimulasi bentuk tulisan terhadap perkembangan bahasa/bicara anak $(\mathrm{p}=0,40)$.

\section{Pembahasan}

Perubahan pola pikir dan pemahaman ibu ternyata berdampak pada HOME. Akhir bulan ketiga dan keenam terjadi peningkatan HOME. Saat evaluasi, hasil lain yang didapatkan pada kelompok satu, ibu umumnya lebih mudah menangkap kata-kata petugas saat ditunjukkan tahap stimulasi dalam bentuk gambar dan mempraktekkan langsung ke anak. Pada kelompok dua, $65,4 \%$ ibu tidak membaca buku pedoman stimulasi, $43 \%$ malas membaca karena tulisan terlalu kecil, tidak sempat membaca, membaca tetapi tidak selesai, sebagian lagi mengatakan ingin membaca tetapi tidak sempat karena sibuk. Duapuluh empat koma

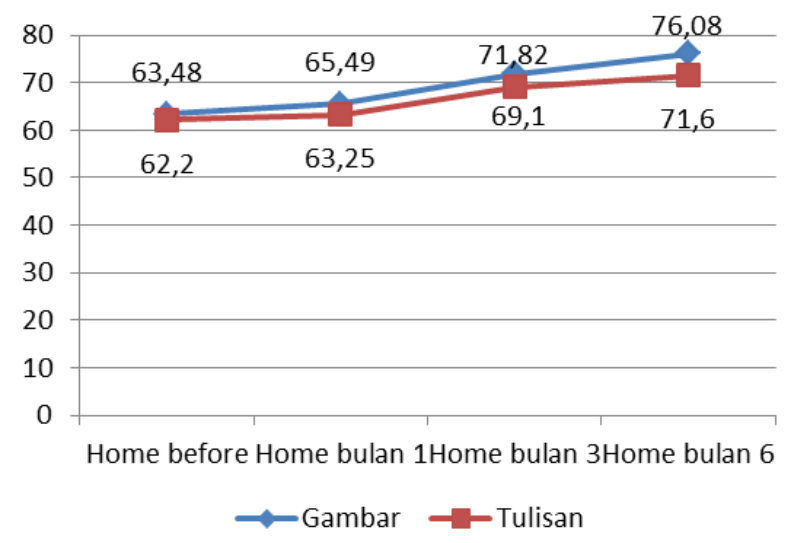

Gambar 1. Grafik HOME selama enam bulan pemantauan 


\section{DDST anak sebelum dan sesudah stimulasi}

kelompok 1 perkembangan anak normal

- kelompok 1 perkembangan anak suspek delayed

- kelompok 2 perkembangan anak normal

- kelompok 2 perkembangan anak suspek delayed

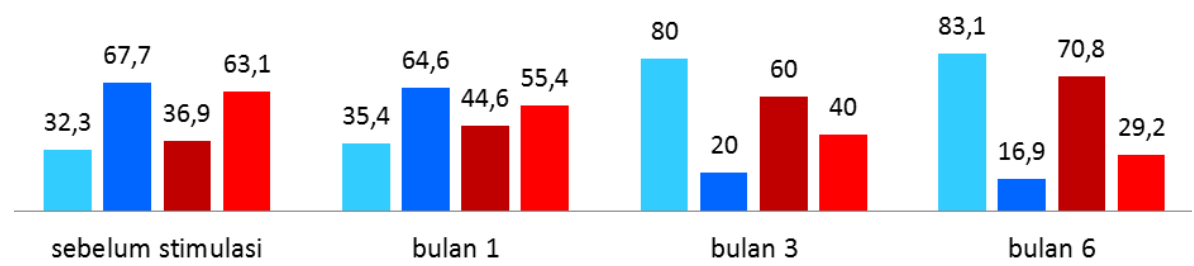

Gambar 2a. Grafik perkembangan anak antara kelompok satu (kelompok gambar) dan kelompok dua (kelompok tulisan) .

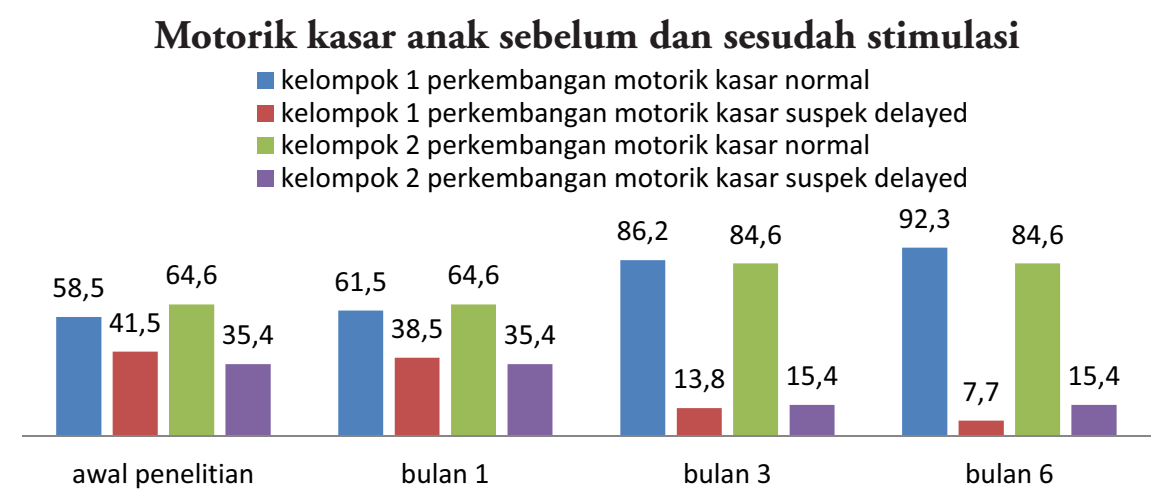

Gambar 2b. Pengaruh stimulasi pada perkembangan motor kasar anak

\section{Motorik halus}

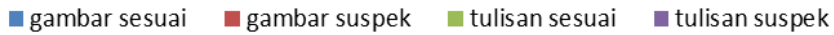

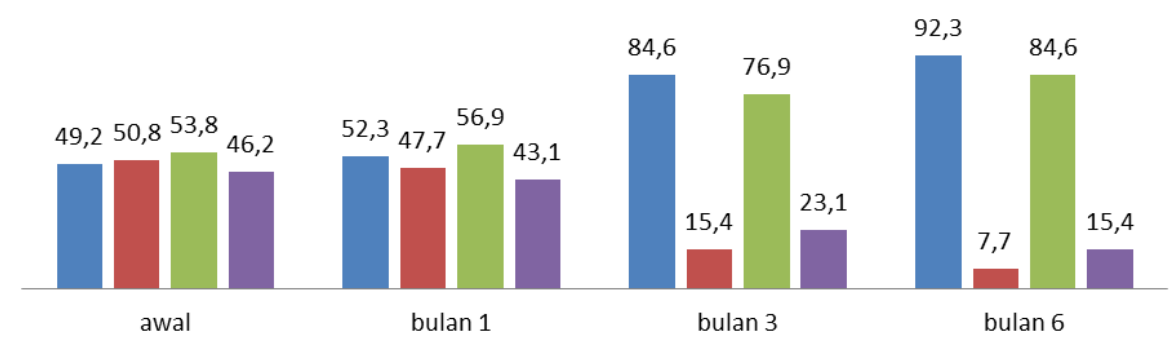

Gambar 2c. Pengaruh stimulasi pada perkembangan motor halus anak

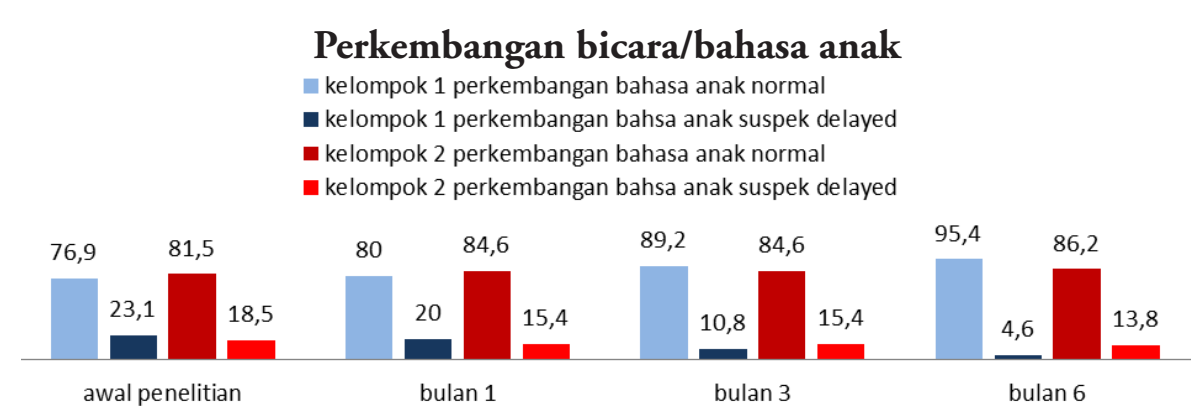

Gambar 2d. Pengaruh stimulasi pada perkembangan bicara anak 


\section{Perkembangan personal sosial anak}

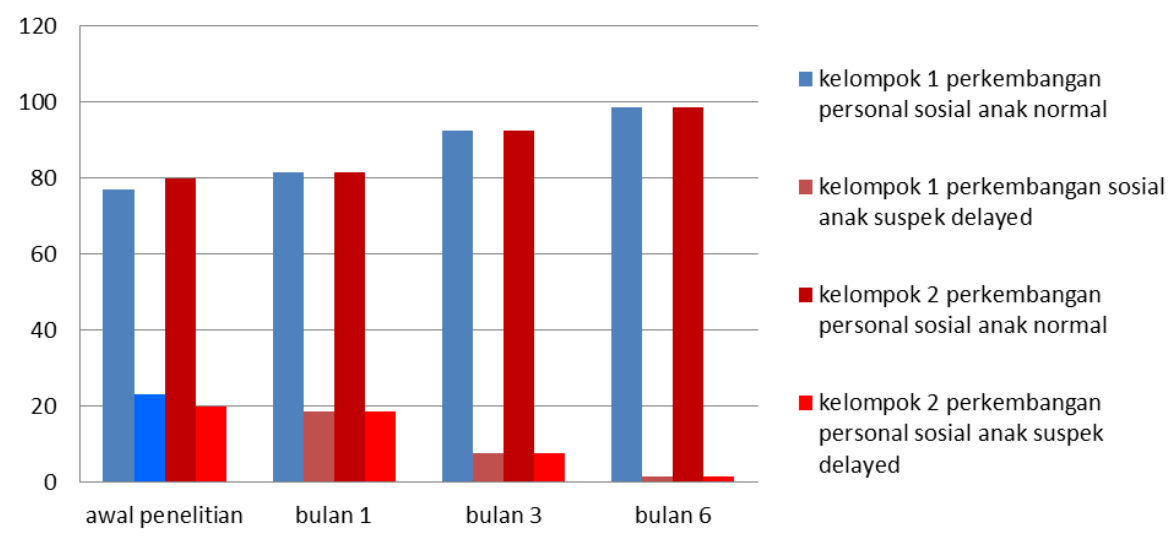

Gambar 3. Pengaruh stimulasi pada perkembangan personal sosial anak

enam persen ibu yang sudah membaca mengatakan bingung atau kurang mengerti isi buku. Hanya $10 \%$ yang mengatakan sudah membaca dan memahami isi buku. Tidak ada perbedaan tingkat pendidikan ibu antara yang membaca dengan yang tidak membaca buku.

Grantham-McGregor dkk ${ }^{5}$ meneliti pengaruh stimulasi psikososial terhadap perkembangan anak. Kelompok pertama mendapat kunjungan setiap dua minggu sekali, ibu diberi pelatihan cara bermain dengan anak mereka. Kelompok lainnya mendapat kunjungan sebulan sekali. Sementara itu, kelompok kontrol adalah kelompok yang sama sekali tidak mendapat kunjungan. Perkembangan anak dinilai satu tahun kemudian. Hasil akhir didapatkan kelompok anak yang mendapat kunjungan dan stimulasi setiap dua minggu mengalami perkembangan lebih tinggi dibanding kelompok lainnya.

Hasil penelitian ini mendapatkan bahwa setelah dilakukan stimulasi pada kelompok kasus dan kontrol, terjadi peningkatan perkembangan motor kasar dan motor halus anak. Hal tersebut sesuai dengan penelitian Sharma dan $\mathrm{Nagar}^{6}$ di India pada anak usia 0-18 bulan. Hasil penelitian menunjukkan bahwa bayi dan anak yang diberi intervensi, seperti memberikan mainan yang merangsang kemampuan perkembangan anak dan meningkatkan keterlibatan orangtua dalam mengasuh anak, memastikan rumah dalam keadaan aman, serta memberikan pemahaman orangtua terhadap milestone perkembangan anak, hasil pemeriksaan motornya lebih baik. Keberhasilan suatu stimulasi tidak tergantung pendidikan orangtua, tetapi ditentukan efektivitas dan kesinambungan stimulasi pada anak.

Terdapat perbedaan pengaruh pelatihan stimulasi pada ibu dalam bentuk gambar dan tulisan terhadap perkembangan personal sosial dan kemampuan bicara dan bahasa anak. Pada kelompok satu, stimulasi berhubungan dengan perkembangan personal sosial dan kemampuan bicara dan bahasa anak pada bulan pertama dan ketiga, tetapi tidak pada bulan keenam. Sementara itu, pada kelompok dua, terjadi peningkatan pada perkembangan personal sosial dan kemampuan bicara dan bahasa anak, tetapi tidak berhubungan dengan stimulasi yang diberikan.

Grantham-McGregor $\mathrm{dkk}^{7}$ meneliti 152 anak usia 6-30 bulan di Jamaika. Pelatihan berupa aktifitas yang dapat dilakukan bersama dengan anak diberikan pada ibu, seperti membuat mainan sederhana di rumah dan membacakan buku cerita ternyata signifikan meningkatkan perkembangan bahasa anak, terutama perbendaharaan kata yang mudah dipahami oleh anak.

Aboud $\mathrm{dkk}^{8}$ meneliti 302 anak di Bangladesh dengan kisaran usia antara 8 sampai 20 bulan. Para ibu diberi pelatihan tentang melatih anak makan sendiri dan cara berinteraksi dengan anak selama mereka bermain. Setelah itu, penilaian HOME dilakukan beserta perkembangan bicara anak. Hasilnya, anak dengan nilai HOME yang lebih tinggi mendapat stimulasi lebih baik dibanding anak dengan nilai HOME rendah. Pada anak dengan nilai HOME lebih baik juga didapatkan peningkatan kemampuan bicara anak. 
Armecin $\mathrm{dkk}^{9}$ mengatakan bahwa intervensi berupa program kesehatan, nutrisi, dan program yang melibatkan keluarga, serta kunjungan rumah signifikan meningkatkan kognitif anak, kemampuan bahasa ekspresif dan reseptif, motor kasar, motor halus dan personal sosial, terutama pada anak usia 2-3 tahun dan pada anak yang mengikuti program paling sedikit selama 17 bulan. Sebaliknya, penelitian di Cali, Colombia, mendapatkan hasil bahwa tidak ada hubungan antara waktu atau durasi lamanya pemberian intervensi dengan perkembangan anak. Penelitian ini mempunyai keterbatasan karena hanya berlangsung selama 6 bulan.

Cohen $\mathrm{dkk}^{10}$ meneliti pengaruh interaksi antara pengasuh dan anak terhadap perkembangan bahasa reseptif anak. Dari 50 anak yang diteliti, Cohen mendapatkan anak dengan perkembangan bicara lebih baik berasal dari kelompok yang pengasuhnya sering berbicara dan berinteraksi dengan anak dalam bahasa verbal maupun nonverbal bersifat positif. Sebaliknya, anak yang pengasuhnya bersifat otoriter perkembangan bicara anak kurang.

Milteer $\mathrm{dkk}^{11}$ menyatakan bahwa permainan berperan pada sosial, emosional, kognitif, dan kemampuan fisik yang lebih baik pada anak. Permainan juga membuat anak menjadi lebih kreatif dan mudah berinteraksi dengan anak lain. Oleh karena itu, agar anak dapat mencapai potensi maksimal perkembangan mereka maka penting bagi para orang tua, pendidik, dan dokter anak untuk menyadari pentingnya waktu bermain bagi anak.

Pada kelompok kasus, akhir bulan ke-6 pemantauan, didapatkan tiga anak dengan perkembangan meningkat di atas rata-rata (advanced), dua anak diasuh ibu kandung yang kebetulan berprofesi sebagai guru playgroup dan aktif memberikan stimulasi. Demikian pula pada kelompok kontrol didapatkan dua anak dengan perkembangan advance setelah stimulasi, menonjol dibanding anak seusianya.

Santos $\mathrm{dkk}^{12}$ mendapatkan bahwa di negara berkembang, perkembangan kognitif anak meningkat dengan adanya intervensi berupa stimulasi dini. Anak yang tinggal di dalam rumah dengan stimulasi yang baik maka perkembangan kognitif anak juga lebih baik. Sebaliknya, lingkungan keluarga yang kurang baik dan kurang stimulasi menyebabkan perkembangan kognitif anak kurang pada saat anak usia pra sekolah kelak.

Akhir penelitian, meskipun perkembangan anak pada kelompok kasus maupun kontrol mengalami peningkatan yang sama, jumlah anak yang mengalami peningkatan lebih baik terdapat pada kelompok yang ibunya mendapat pelatihan cara stimulasi dengan menggunakan metode gambar dibandingkan kelompok kontrol yang ibunya diberi pelatihan dengan menggunakan metode tulisan. Hal tersebut menunjukkan bahwa pemahaman dan pengertian ibu/pengasuh terhadap cara stimulasi berperan penting karena akan berdampak terhadap cara stimulasi ibu/pengasuh pada anak. Anak dan orang tua/pengasuh yang lebih aktif dan simultan melakukan stimulasi menunjukkan kemajuan perkembangan yang lebih baik.

\section{Kesimpulan}

Cara stimulasi oleh ibu dengan metode gambar lebih baik pengaruhnya terhadap perkembangan anak usia kurang dari tiga tahun dibandingkan dengan metode tulisan. Pengembangan buku pedoman stimulasi yang menggunakan gambar perlu dilakukan agar lebih mudah dipahami, dimengerti, dan lebih mudah diterapkan oleh masyarakat, khususnya para ibu/ pengasuh dari semua tingkat pendidikan.

\section{Daftar pustaka}

1. Gde Ranuh IGN. Gambaran tumbuh kembang anak di Indonesia. Malang:EGC:2006.h.14.

2. Darto S, Gunawan PI, Erny. Child's brain development. Dalam: Save our child's brain! Surabaya: Departemen IKA FK UNAIR; 2012.h.1-22.

3. Irwanto. Impact of early stimulation on brain development. Dalam: Save our child's brain! Surabaya: Departemen IKA FK UNAIR; 2012.h.199-233.

4. Departemen Kesehatan Republik Indonesia. Pedoman pelaksanaan stimulasi deteksi dan intervensi dini tumbuh kembang anak di tingkat pelayanan kesehatan dasar. Jakarta: Departemen Kesehatan, Direktorat Jenderal Pembinaan Kesehatan Masyarakat; 2006:1-95.

5. Grantham McGregor S, Schofield W, Powell C. Development of severely malnourished children who received psychosocial stimulation: six year follow up. Pediatrics 1987;79:247-54.

6. Sharma S, Nagar S. Influence of home environment on psychomotor development of infants in Kangra district of Himachal Pradesh. J Soc Sci 2009;21:225-9.

7. Grantham McGregor S, Yin BC, Cueto S, Glewwe P, 
Richter L, Strupp B. Developmental potential in the 5 years for children in developing countries. Lancet 2007;369:60-70.

8. Abound FE, Akhter S. A cluster-randomized evaluation of a Bangladesh stimulation and feeding intervention in Bangladesh. Pediatrics 2011;127:1191-7.

9. Armecin MH, Putcncik DL, Koegel RL, Stolen K. Cumulative effect of perinatal complications and deprived environment on physical, intelectual, and social development of preschool children in Filipino. Eur J Clin Nutr 2012;1038-43.
10. Cohen SE, Beckwith L, Parmelee AH. Reseptive language development in preterm children as related to caregiverchild interaction. Pediatrics 2012;20:e16-9.

11. Milteer RM, Ginsburg KR, Mulligan DA. The importance of play in promoting healthy child development and maintaining strong parent-child bond:Focus on children in poverty. Pediatrics 2012:129:e204-213.

12. Santos DN, Assis AM, Bastos AC, Santos LM, Santos CA, Strina A, dkk. Determinant of cognitive function in childhood: A cohort study in a middle income context. BioMed 2008;8:202-4. 